\title{
Environmental Awareness and Plastic Recycling Behaviour of Nigerian Undergraduates
}

\section{Loveth Aikowe}

Envigogika 16 (1) - Inspirations /Inspirace

Published/ Publikováno 11. 10. 2021

DOI: $10.14712 / 18023061.626$

\begin{abstract}
Several prior studies globally have linked education with environmental awareness and behaviour, however there is a need to address the research gap in developing countries on the impact environmental education can have on pro-environmental awareness and in promoting pro-environmental behaviours (PEB) especially among university students. This paper takes into account the influence of social norms on PEB such as plastic recycling and promotes the notion of sustainable education in Higher institutions of learning in Nigeria. Recommendations for policy makers and universities are also reflected upon as Nigerian universities are urged to take pro-active steps towards adapting their curriculums and environmental volunteering activities. Furthermore, the study suggest sustainability literacy tests are incorporated into Nigerian university educational policies in other to promote pro-environmental behaviours among students.
\end{abstract}

\section{Key words}

Sustainabilty; Plastic recycling; Environmental awareness; Environmental education; Pro-environmental behaviour

\begin{abstract}
Abstrakt
Několik předchozích studií z celého světa spojovalo vzdělávání s environmentálním povědomím a chováním, nicméně v rozvojových zemích je třeba řešit mezeru ve výzkumu dopadu environmentálního vzdělávání na proenvironmentální povědomí a podporu proenvironmentálního chování, zejména mezi vysokoškolskými studenty. Tento článek bere $v$ úvahu vliv sociálních norem na proenvironmentální chování, jako je recyklace plastů, a podporuje myšlenku udržitelného vzdělávání na vysokých školách v Nigérii. Jsou zde také uvedena doporučení pro tvưrce politik a univerzity, nebot́ nigerijské univerzity jsou vyzvány, aby podnikly proaktivní kroky k úpravě svých studijních programů a dobrovolnických aktivit v oblasti životního prostředí. Studie dále navrhuje, aby byly do vzdělávací politiky nigerijských univerzit začleněny testy gramotnosti $v$ oblasti udržitelného rozvoje, které by podpořily proenvironmentální chování studentů.
\end{abstract}

\section{Klíčová slova}

Udržitelnost; recyklace plastů; environmentální povědomí; environmentální vzdělávání; pro-environmentální chování 


\section{Introduction}

Pro-environmental behaviour (PEB) has been described by authors as any action conveyed with little or no adverse environmental consequence such as plastic recycling, energy conservation or green purchasing (1). However, PEB is influenced by a number of factors, external or internal such as individual's environmental knowledge or attitude (2), one of such factors is education.

Although, many previous studies have correlated education and environmental awareness and behaviours, there is a wide research gap in developing countries on the impact environmental education can have on pro-environmental awareness and subsequent PEBs especially among university students. This is because majority of prior related studies have mainly been focused in developed countries.

\section{Plastic Pollution and recycling in Nigeria}

Nigeria like most African continues to tackle environmental challenges in recent years (3). One of the most disturbing is the exponential increase of municipal solid waste (MSW) production due to rapid urbanization and population increase (estimated population to be more than 200 million) (4). Globally, a key contributor to MSW in the last 10 years is plastic waste generated mainly from the packaging industries (5). Furthermore, over 50\% of 13 million tons of plastic produced between 2015 and 2016 in Nigeria are single-use plastic products, amassing the solid waste predicament (6). The current prevailing practices for waste disposal include haphazard burning and dumping of waste refuse by the roadsides or dumpsites (7) posing serious health risks and wellness of the people and environment. However, a feasible solution is seen in plastic recycling (8) and increasing public awareness and education on its benefits (9).

Plastic recycling is an industrial process that begins with plastic waste sorting (10). Plastic materials gotten from a variety of polymers with high molecular mass are considered a waste stream with potential for recycling and recovery (11). For instance, low density polyethylene has been majorly imported into Nigeria in the last 20 years and then used to produce a large number of plastic products (e.g., cling wraps, grocery bags, sandwich bags, refuse bags, bubble wrap, fertilizer sacs, and plastic bottles). However, these are often used just once and discarded (8). Additionally, polypropylene has also been utilized in Nigeria's manufacturing industries on a huge scale. These materials are then further used to produce other plastic products like butter containers, straws, heavy-duty bags, biscuit wrappers and pre-scription syrup bottles (11).

Although plastic is considered to have high a recycling and recovery capability, the rate of recycling which is reported to be less than $12 \%$ in Nigeria (11) does not match the fast pace at which plastics are being produced. Hence, for MSW management to become successful, plastic recycling and recovery habits need to increase, while at the same time production of new plastic products should decline.

\section{Environmental Awareness}

Environmental awareness has been argued to have a multidimensional construct in the past. However, following many years of steady improvement of related concepts, pro-environmental awareness is deemed an aspect of environmental literacy and frequently linked with pro-environmental knowledge (12). All these terms are collaborative. An increase in 
environmental knowledge will often surmount to a similar rise in environmental awareness, concern, and even PEBs. In general, environmental awareness is regarded as an essential part of environmental awareness (13).

One method to advance students' environmental awareness is through Sustainability education (13). Education for sustainable development (ESD) includes a dynamic learning process that allow students to attain sustainable development (SD) knowledge and skills.

Irrespective of global or local environmental literacy, being educated on environmental issues should be inclusive of all age groups either by formal or informal education (14). In Nigeria secondary schools, young people are introduced to environmental problems like climate change, water, waste, and land pollutions (15). Furthermore, HEIs are tasked with providing guidance and Knowledge on programs and activities related to sustainability.

In Nigeria, the notion of sustainable education is addressed in the form of environmental education. This can be recognized through Nigeria's policy documents such as Nigeria's Agenda 2021 and the National Education Policy, which refers to environmental education (15). The joint admissions and matriculation board of Nigeria (JAMB) have a brochure listing out courses in Nigeria's HEIs, and this list allows the deduction that there is currently no HEI offering a Sustainability degree (15). This omission is not overlooked as it was included in UNDESD 2014 final report.

\section{Influence of Social Norms}

In plastic waste sorting among Nigerian university students, findings have revealed that subjective norm creates the foundation of social expectations on students to sort plastic waste (16). Subjective norms as recommended by Ajzen (17) contains two attributes, injunctive norms (i.e., what is expected of the students by individuals they look up to) and descriptive norms (what social norm determines is appropriate behaviour) (18). Aikowe and Mazancová (16) study further reveals subjective norms towards plastic sorting intention to be significant. Additionally, over $65 \%$ of students from two Nigerian universities reported unfavourably to their peers partaking in plastic separation for recycling. Which indicates, most of the students did not agree that their classmates were sorting plastic.

\section{Recommendation}

A primary recommendation for universities in Nigeria is to develop their extracurricular activities as it relates to environmental behaviour as one study in Nigeria revealed that over $80 \%$ of the student sample population do not belong to an environmental volunteering program within or outside the university (16). These projects may include hands-on internships or training for students by collaborating with federal or state environmental bodies or other environmental agencies in the region. This will allow students gain more practical knowledge on recycling and other PEBs.

Another recommendation is that universities take the initiatives themselves by starting with something simple like placing recycling bins around the university premises and also find creative ways to encourage students to sort their solid waste, recycle and take part in other PEBs

Finally, it is highly recommended that HEIs in Nigeria and other universities worldwide take advantage of the abundance of a sustainability assessment tool such as Sulitest.org, assessment of sustainabilty knowledge (ASK) or various others and employ these tools. 
Periodic assessment using sustainability literacy test (SLT) measures will help HEIs identify and aim their sustainability programmes for the advancement of students as well as educators.

\section{References:}

(1) Steg, L.; Vlek, C. Encouraging Pro-Environmental Behaviour: An Integrative Review and Research Agenda. J. Environ. Psychol. 2009, 29 (3), 309-317. https://doi.org/10.1016/J.JENVP.2008.10.004.

(2) Vicente-Molina, M. A.; Fernández-Sainz, A.; Izagirre-Olaizola, J. Does Gender Make a Difference in Pro-Environmental Behavior? The Case of the Basque Country University Students. J. Clean. Prod. 2018, 176, 89-98. https://doi.org/10.1016/j.jclepro.2017.12.079.

(3) Dumbili, E.; Henderson, L. The Challenge of Plastic Pollution in Nigeria. In Plastic Waste and Recycling; 2020; pp 569-583. https://doi.org/10.1016/b978-0-12-8178805.00022-0.

(4) Ike, C. C.; Ezeibe, C. C.; Anijiofor, S. C.; Nik Daud, N. N. Solid Waste Management in Nigeria: Problems, Prospects, and Policies. J. Solid Waste Technol. Manag. 2018, 44 (2), 163-172. https://doi.org/10.5276/jswtm.2018.163.

(5) Heidbreder, L. M.; Bablok, I.; Drews, S.; Menzel, C. Tackling the Plastic Problem: A Review on Perceptions, Behaviors, and Interventions. Science of the Total Environment. 2019, pp 1077-1093. https://doi.org/10.1016/j.scitotenv.2019.02.437.

(6) Duru, R. U.; Ikpeama, E. E.; Ibekwe, J. A. Challenges and Prospects of Plastic Waste Management in Nigeria. Waste Dispos. Sustain. Energy 2019, 1 (2), 117-126. https://doi.org/10.1007/s42768-019-00010-2.

(7) Ayodele, T. R.; Alao, M. A.; Ogunjuyigbe, A. S. O. Recyclable Resources from Municipal Solid Waste: Assessment of Its Energy, Economic and Environmental Benefits in Nigeria. Resour. Conserv. Recycl. 2018, 134, 165-173. https://doi.org/10.1016/j.resconrec.2018.03.017.

(8) Mwanza, B. G.; Mbohwa, C.; Telukdarie, A. Strategies for the Recovery and Recycling of Plastic Solid Waste (PSW): A Focus on Plastic Manufacturing Companies. In Procedia Manufacturing; 2018; Vol. 21, pp 686-693.

https://doi.org/10.1016/j.promfg.2018.02.172.

(9) Adeniran, A. E.; Nubi, A. T.; Adelopo, A. O. Solid Waste Generation and Characterization in the University of Lagos for a Sustainable Waste Management. Waste Manag. 2017, 67, 3-10. https://doi.org/10.1016/j.wasman.2017.05.002.

(10) Shen, L. Chapter 13 - Plastic Recycling. In Handbook of Recycling; 2014; pp 179190.

(11) Babayemi, J. O.; Nnorom, I. C.; Osibanjo, O.; Weber, R. Ensuring Sustainability in Plastics Use in Africa: Consumption, Waste Generation, and Projections. Environ. Sci. Eur. 2019, 31 (1). https://doi.org/10.1186/s12302-019-0254-5.

(12) Fu, L.; Zhang, Y.; Xiong, X.; Bai, Y. Pro-Environmental Awareness and Behaviors on Campus: Evidence from Tianjin, China. Eurasia J. Math. Sci. Technol. Educ. 2018, 14 (1), 427-445. https://doi.org/10.12973/ejmste/77953. 
(13) Zhang, H.; Liu, J.; Wen, Z. guo; Chen, Y. X. College Students' Municipal Solid Waste Source Separation Behavior and Its Influential Factors: A Case Study in Beijing, China. J. Clean. Prod. 2017, 164, 444-454. https://doi.org/10.1016/j.jclepro.2017.06.224.

(14) Akkor, Ö.; Gündüz, Ş. The Study of University Students' Awareness and Attitude towards Environmental Education in Northern Cyprus. Eurasia J. Math. Sci. Technol. Educ. 2018, 14 (3), 1057-1062. https://doi.org/10.12973/ejmste/81366.

(15) Akeel, U.; Bell, S.; Mitchell, J. E. Assessing the Sustainability Literacy of the Nigerian Engineering Community. J. Clean. Prod. 2019, 212, 666-676. https://doi.org/10.1016/j.jclepro.2018.12.089.

(16) Aikowe, L.D.; Mazancová, J. Plastic Waste Sorting Intentions among University Students. Sustainability 2021, 13, 7526. https://doi.org/10.3390/su13147526.

(17) Ajzen, I. The Theory of Planned Behavior. Organ. Behav. Hum. Decis. Process. 1991, 50 (2), 179-211. https://doi.org/10.1016/0749-5978(91)90020-T.

(18) Wan, C.; Shen, G. Q.; Choi, S. Experiential and Instrumental Attitudes: Interaction Effect of Attitude and Subjective Norm on Recycling Intention. J. Environ. Psychol. 2017, 50, 69-79. https://doi.org/10.1016/j.jenvp.2017.02.006. 